\title{
Measuring innovation: A state of the science review of existing approaches
}

\author{
Philipp ter Haar (iD \\ University of Applied Sciences Hamburg (Germany) \\ p.terbaan@tresolutions.de
}

Received January, 2018

Accepted April, 2018

\begin{abstract}
Purpose: The level of innovation is essential for a company's or country's competitive advantage and the ways to measure innovation are manifold. The review aims to give an overview over the continuously growing body on approaches to measure innovation.

Design/methodology: A new definition of innovation measuring is proposed. Based on this definition a structured approach for researching the literature was applied. A selection of 30 advances is discussed and a 4-level-of-analysis-framework is applied to review the broad research on measuring innovation on individual, work team, company and country level.
\end{abstract}

Findings: The narrative review shows that specific measuring frameworks exists for each level of analysis. Output oriented indicators can be found on all levels, they are complemented by potential enablers on country level, process indicators on company and project level and behavioural indicators on individual level. Approaches specifically focussing on work teams could not be found.

Research limitations/implications: Further research is needed on specific advances on measuring innovation on work-team level.

Practical implications: By discussing key characteristics of the reviewed studies, the analysis will help decision makers to choose a fitting approach and support researchers by identifying open fields of research. It is recommended to research on advances to measure innovation on work team level to close the existing gap.

Originality/value: While influences on innovation are extensively discussed a comprehensive overview over the approaches to identify the effects of modifying these influences is missing. This paper intends to closes this gap.

Keywords: Innovation measuring, Innovation controlling, Literature review, Innovation management

Jel Codes: O31, O32, M10

\section{Introduction}

It is broadly accepted in today's literature that it [concept of innovation] is considered one of the essential ingredients of competitive advantage given that it is an intangible component that is difficult for competitors to replicate.'(Marin-Garcia, Perez-Peñalver, Vidal-Carreras \& Maheut, 2012, p. 920). Thus, this topic is on the one 
hand in the focus of nowadays research and on the other hand many companies invest (significantly) to improve their innovation performance in the next couple of years.

While companies are investing it is generally of high relevance to accompany these investments with frameworks which are able to measure the investment's success. To just name a few, some companies use an adapted form of the balance score card - the innovation balance scorecard - to measure innovation (Fischer, Möller, \& Schultze, 2015, p. 646), others are measuring the return on R\&D (Vahs \& Brem, 2015, p. 646). Alternatively, Bloomberg is offering the "Bloomberg innovation index" to measure innovation (Coy, 2015, p. 1) while other authors use the so called "Innovation Capacity Indicator" (López-Claros \& Mata, 2012, p. 1).

The topic of measuring and controlling innovation is broadly discussed within the literature and by various organisations responsible for creating general innovation indexes or measuring a company's innovation. There has been a significant rise in the number of published articles on innovation, innovation measuring and innovation controlling since 2001 (for details please refer to Figure 1).

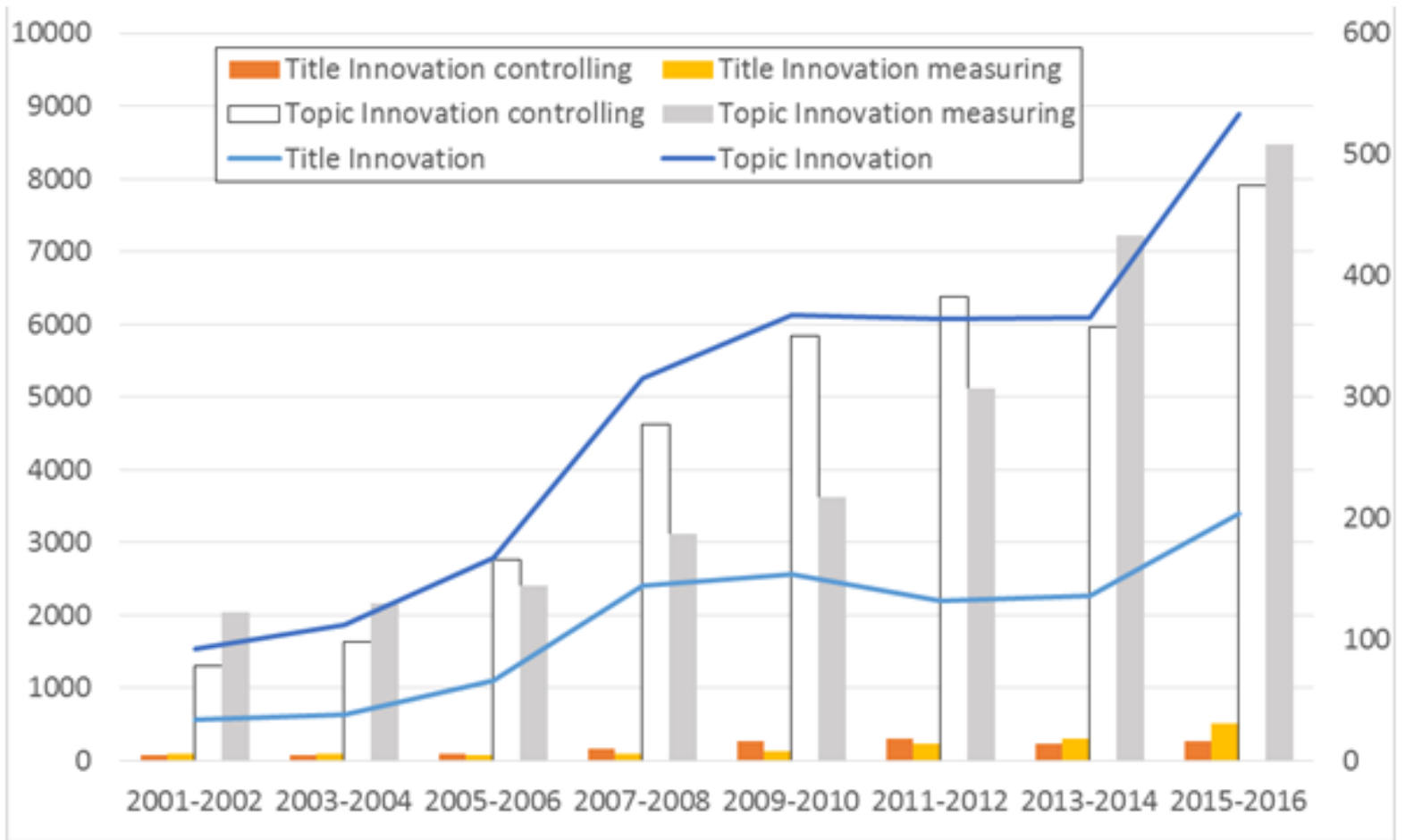

Figure 1. Growth in published papers in the field of innovation. Note: The literature re-search was undertaken in the Web of Science using innovation and innovation controlling as keywords in the subject fields business, management and business finance)

However, it is unclear whether it is exhaustive or whether there are still areas requiring further research. To facilitate the analysis and improve clarity it is recommendable to cluster the manifold approaches in groups. In a similar context Anderson et al. used a framework of 4 levels to evaluate innovation and creativity in organizations: the individual, the work team, organizational, and multi-level approaches (Anderson, Potocnik \& Zhou, 2014, 1302f). Within this study it is evaluated whether this idea can be transferred on innovation measuring to cluster the identified approaches:

- The assessment of particular skills which are supposed to lead to innovativeness on an individual level are highly relevant e.g. for universities to adapt their curriculum or HR in the hiring process. Employee level innovation metrics also help on deciding about rewards and recognition (Goffin \& Mitchell, 2010, p. 302). This level of analysis should therefore be taken into account within the present review. 
- It is also highly relevant for companies to be able to judge on the innovation performance of a single work team or project team. Knowing the "as is" status of a team's innovation performances enables managers to on the one hand decide which teams need specific measures to in-crease their innovativeness and on the other hand to control the success of an implemented measure, in case the level of innovation has increased.

- Today, most innovations are based not on a single persons or teams but on the effort of the whole company or at least teams working across business units (Fischer et al., 2015, p. 642). To represent this situation, approaches to measure innovation are also required on organizational level. Even though there is an overlapping area with regards to the work team level in which exact definitions are difficult to apply, within this review advances to evaluate multi-project teams and business units consisting of more than one work or project team respectively will be evaluated within this category.

- However, 'Every country wants to foster a culture of innovation' (Coy, 2015, p. 1). To do so, one must know which countries succeed in this task to learn from their success. Because it is necessary to be able to evaluate the innovation level of a country or region, relevant advances exist which cannot not be categorized to one of the other levels. Thus, this level of measuring should be added to the framework used by Anderson et al.

- Anderson et al. are evaluating studies on creativity and innovation and were also including multi-level research into their review (Anderson et al., 2014) Within the context of this paper taking multilevel analysis' of innovation into account will not be reasonable. Even though work teams and projects might also be defined as small subordinated units of organizations, the individual, the organizational and the country level differ too much from each other. So, a specific category for measuring innovation based on multilevel analysis is not required.

To sum up, on the one hand Anderson et al. already proved that this framework is working. On the other hand, it allows a plausible grouping in a mutual exclusive but collectively exhaustive structure of advances measuring innovation while only minor adjustments are required. This framework will therefore be used within this study. By reviewing representative academic approaches and business tools clustered in the four levels individual, work team, company and country (see Figure 2), this study pursues two objectives: assessing open fields of today's research and supporting decision makers to identify the tool fitting to their specific need.

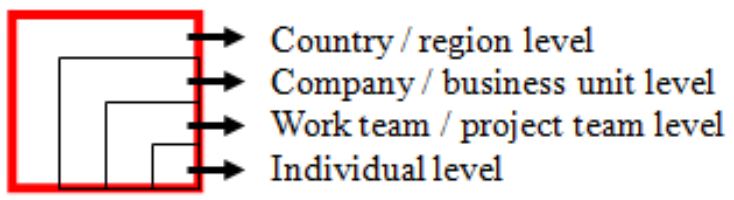

Figure 2. Levels of Analysis for approaches to measure innovation

Thus, firstly a definition of measuring innovation will be given and the structured approach to identify approaches described in academic literature and offered as business services will be specified. Secondly, this review will give an overview over 30 approaches to measure innovation which are grouped into the four levels described above. Then, it will be discussed whether the existing approaches describe the topic exhaustively or there is a need for further research.

\section{Methodology}

The study aims to present a comprehensive overview over existing and relevant methods of innovation measuring not only described in academic literature but also offered as tools to customers. A proven review strategy based on stages was applied (Pittaway, Robertson, Munir, Denyer \& Neely, 2004, 139f; Rousseau, 
Manning \& Denyer, 2008) to identify the relevant approaches. The following steps were taken by the author (Spender, Corvello, Grimaldi \& Rippa, 2017, p. 5):

i) Based on a preliminary review of the literature on the topic of innovation, the author identified a set of key words by using the mindmapping technique. Exemplary key words were "innovation", "measuring", "assessment" and "controlling".

ii) Search strings were used to find the relevant contributions, e.g. the string [innovat* AND measure* OR control* OR assess*] was used at the beginning.

iii) This string was used for an initial search in Google Scholar to determine additional key words. For example, additional words such as "performance", "capability", "R\&D", "indicator" and "index" were found to be relevant and added to the analysis.

iv) As a base a search using the string ["measur* innovat*" OR "control* innovat*"] was undertaken in three search engines: Elsevier's Scopus (576 contributions), Web of Science (372) and EconBiz (240).

v) Due to the highest number of resulting contributions, Scopus was selected to apply the strings identified in step ii) and iii). These strings were continuously refined up to the most complex. 321 contributions were gained using the final string [(TITLE-ABS-KEY ("measur*innovate*" OR "control*innovat*" OR "measure* R\&D" OR "innovation index" OR "measure* innovat* performance")) AND (performance) AND (LIMIT-TO (SUBJAREA, "BUSI") OR LIMIT-TO (SUBJAREA, "ENGI") OR LIMIT-TO (SUBJAREA, "ECON"))]. The author is glad to provide the full list to anyone interested

vi) Inclusion and exclusion criteria were defined to further refine the results (see Table 1). The reasoning was to include all methods and tools included which describe a way to measure innovation independent from the measured object (e.g. single product, individual or country). Due to the fact that organizations or specialized companies offer to evaluate innovativeness, this aspect was included as well in the list of criteria as long as the measuring method could be obtained.

\begin{tabular}{|l|l|}
\hline \multicolumn{2}{|c|}{ Inclusion Criteria } \\
\hline Criteria & Reason for inclusion \\
\hline Theoretical papers & $\begin{array}{l}\text { Provide the working assumptions used in this study and the study on } \\
\text { existing tools }\end{array}$ \\
\hline $\begin{array}{l}\text { Qualitative and quantitative } \\
\text { empirical studies }\end{array}$ & To include all empirical evidence \\
\hline $\begin{array}{l}\text { Study books / lecture } \\
\text { documents }\end{array}$ & $\begin{array}{l}\text { To describe tools for measuring innovation relevant for students and } \\
\text { practitioners in a concise manner }\end{array}$ \\
\hline $\begin{array}{l}\text { Tools offered by companies } \\
\text { or organizations }\end{array}$ & $\begin{array}{l}\text { To describe tools and prove their applicability in reality for measuring } \\
\text { innovation. These were only included if the methodology of the } \\
\text { approach was described. }\end{array}$ \\
\hline \multicolumn{1}{|c|}{ Exclusion criteria } \\
\hline Criteria & Reason for exclusion \\
\hline $\begin{array}{l}\text { Studies on activities / } \\
\text { methods to increase } \\
\text { innovation }\end{array}$ & $\begin{array}{l}\text { Activities / methods to improve innovation performance or } \\
\text { capabilities are different from measuring it. }\end{array}$ \\
\hline $\begin{array}{l}\text { Influencing factors on } \\
\text { innovativeness }\end{array}$ & $\begin{array}{l}\text { The study shows an overview over the existing tools / methods for } \\
\text { measuring innovation and does not intend to develop an own } \\
\text { approach based on existing influencing factors. }\end{array}$ \\
\hline
\end{tabular}

Table 1. Inclusion and exclusion criteria

vii) These criteria were used to assess the contributions gained from Scopus in two steps: to begin with, the titles and keywords of the articles were evaluated based on the inclusion and exclusion criteria, secondly, the abstracts of supposedly relevant articles were analyzed accordingly. However, the vast 
majority of literature is addressing the need for being innovative and activities or methods to increase the level of innovation and were excluded. So finally, 24 approaches fulfilled the focus of this review.

viii) To include tools and methods offered by companies or organisations even though they might not have been referenced by Scopus, the author also used the search string from step iv) in Google to ensure the completeness of the search results. While applying the inclusion and exclusion criteria on the 69 results and their linked references, 6 additional approaches from the business sector and country indices were identified.

ix) Finally, the reference sections of the total of 30 approaches was evaluated according to these criteria to assess the search strategy and search for additional approaches. However, additional advances could not be identified.

x) Each approach was assigned to one of the levels described above and evaluated based on the aspects measuring technique and indicators used. During this process themes common to the approaches were identified.

\section{Review of approaches}

A data as well as descriptive analysis of the identified approaches was conducted.

\subsection{Data analysis}

Generally speaking, descriptions of approaches can be found in three different sources: study books or lecture documents, journal articles and as service offered. Naturally, some advances are described in more than one source. To examine the typology of identified approaches and trace the major sources the content analysis method was adopted (Leonidou, Katsikeas \& Coudounaris, 2010, p. 80); (Furrer, Thomas \& Goussevskaia, 2008, p. 5) with regard to the aspects characteristics of approach description and the approaches' measuring technique. The author also considered conducting an analysis of key words. Due to the high percentage of tools described in study books or being offered by companies or organizations - sources which lack specific key words regarding the approach - a meaningful result could not be expected and the idea was dismissed.

The advances were described in three ways: either generally / theoretically (how one should do it) or the applicability was proved in a study / experiment or by showing the results of their regular application. While 12 out of the total of 30 advances (40\%) were described in a general manner, $8(27 \%)$ approaches were applied by the authors.

\begin{tabular}{|l|r|}
\cline { 2 - 2 } \multicolumn{1}{c|}{} & Total (n=30) \\
\hline General description & $40 \%$ \\
\hline Application & $27 \%$ \\
\hline Study & $33 \%$ \\
\hline
\end{tabular}

Table 2. Characteristics of approach description

It is particularly noticeable that all advances with a focus on measuring a country's innovation are actually applied by the authors, presenting a ranking of the world's most innovative countries. While this shows that these tools are working, of course it does not prove the validity of the results or the meaningfulness of the chosen criteria.

Different techniques are used to measure the approaches indicators' (Table 3): quantitative, semi-quantitative and/or qualitative. Semi-quantitative techniques are basically qualitative judgements that are converted to numbers. They differ from quantitative technique in that no attempt is made to use a sophisticated formula to complete the data. For example, the $\mathrm{R} \& \mathrm{D}$ return framework results in 1 single value by multiplying indicators such as e.g. R\&D productivity with R\&D yield (Vahs \& Brem, 2015, p. 648), the Innovation Balanced Scorecard reports single values without resulting in 1 single value (Fischer et al., 2015, p. 646). Qualitative techniques are intuitive judgements (Pappas \& Remer, 1985, p. 15). 


\begin{tabular}{|c|c|c|c|c|c|}
\hline & Quantitative & $\begin{array}{l}\text { Semi- quantitative } \\
\text { \& quantitative }\end{array}$ & Semi-quantitative & $\begin{array}{c}\text { Quantitative \& } \\
\text { qualitative }\end{array}$ & Qualitative \\
\hline Employee & 1 & 1 & 3 & 0 & 0 \\
\hline Team / project & 0 & 2 & 0 & 1 & 1 \\
\hline $\begin{array}{l}\text { Company / } \\
\text { business unit }\end{array}$ & 6 & 0 & 9 & 0 & 0 \\
\hline Country & 6 & 0 & 0 & 0 & 0 \\
\hline Total $(n=30)$ & 13 & 3 & 12 & 1 & 1 \\
\hline Total in $\%$ & $43 \%$ & $10 \%$ & $40 \%$ & $3 \%$ & $3 \%$ \\
\hline
\end{tabular}

Table 3. Measuring technique

It can be stated that nearly all approaches try to quantify the level of innovation, 13 out of the total of 30 advances are even using a quantitative technique to facilitate comparisons, e.g. of countries by showing one resulting score.

With regard to the descriptive analysis the evaluated advances show a great variety in methodology and objective while measuring innovation. The identified approaches for measuring innovation were reviewed clustered in the 4 levels focussing on country level, company level, work team / project team level or the level of the individual (please refer to Table 4).

\begin{tabular}{|c|c|c|c|c|}
\hline \multicolumn{5}{|c|}{ Overview over discussed approaches } \\
\hline Name / Author & $\begin{array}{l}\text { Level of } \\
\text { analysis }\end{array}$ & $\begin{array}{l}\text { Measuring } \\
\text { technique(s) }\end{array}$ & Indicators used & Remarks / short description \\
\hline $\begin{array}{l}\text { Input-Process- } \\
\text { Output-Outcome } \\
\text { Model (IPOO) }\end{array}$ & Company & $\begin{array}{l}\text { Semi- } \\
\text { quantitative }\end{array}$ & $\begin{array}{l}\text { Exemplary selection (Möller, } \\
\text { Menninger \& Robers, 2011): } \\
\text { · Input: } \\
\text { quantitative: personal cost, number } \\
\text { of ideas, training cost per employee } \\
\text { semi-quantitative: work experience of } \\
\text { employees, quality of ideas } \\
\text { · Processing System: } \\
\text { quantitative: hours worked per } \\
\text { project, number of results achieved in } \\
\text { time } \\
\text { semi-quantitative: product / service } \\
\text { quality, progress } \\
\cdot \text { Output: } \\
\text { quantitative: number of patents, } \\
\text { number of new products, average } \\
\text { cost per patent } \\
\text { semi-quantitative: synergy effects, } \\
\text { fundamental research results } \\
\cdot \text { Outcome: } \\
\text { quantitative: increase in sales / profit, } \\
\text { cost reductions } \\
\text { semi-quantitative: product } \\
\text { improvements, customer satisfaction }\end{array}$ & $\begin{array}{l}\text { The quantified elements can be } \\
\text { displayed for example in form of a } \\
\text { spider web chart. } \\
\text { Möller et al., } 2011 \text { are } \\
\text { characterising these indicators as } \\
\text { „qualitative” Due to the fact that a } \\
\text { quantitative visualization by using } \\
\text { a spiderweb diagramme is used, } \\
\text { they have to be categorized as } \\
\text { semi-quantitative } \\
\text { This measuring approach is also } \\
\text { supported by other German } \\
\text { authors, e.g. (Fischer et al., 2015; } \\
\text { Vahs \& Brem, 2015) }\end{array}$ \\
\hline $\begin{array}{l}\text { Innovation } \\
\text { Balanced Scorecard }\end{array}$ & Company & $\begin{array}{l}\text { Semi- } \\
\text { quantitative }\end{array}$ & $\begin{array}{l}\text { Exemplary selection of indicators of } \\
\text { the balanced score card with focus on } \\
\text { increasing innovation success(Fischer } \\
\text { et al., 2015): } \\
\text { - Sales with new products in relation } \\
\text { to required investments } \\
\cdot \text { Time to market } \\
\text { - Market share gained by R\&D }\end{array}$ & $\begin{array}{l}\text { Approach describes } \\
\text { implementation of a balanced } \\
\text { score card with particular focus on } \\
\text { innovation success }\end{array}$ \\
\hline
\end{tabular}




\begin{tabular}{|c|c|c|c|c|}
\hline \multicolumn{5}{|c|}{ Overview over discussed approaches } \\
\hline Name / Author & $\begin{array}{l}\text { Level of } \\
\text { analysis }\end{array}$ & $\begin{array}{l}\text { Measuring } \\
\text { technique(s) }\end{array}$ & Indicators used & Remarks / short description \\
\hline $\begin{array}{l}\text { Innovation Audit } \\
\text { Scorecard }\end{array}$ & Company & $\begin{array}{l}\text { Semi- } \\
\text { quantitative }\end{array}$ & $\begin{array}{l}\text { 'Innovation audits look at not only } \\
\text { performance (an output measure) but } \\
\text { also how this performance was } \\
\text { achieved (a process measure)' (Goffin } \\
\text { \& Mitchell, 2010, p. } 317 \text { ) } \\
\text { Indicators are defined for various } \\
\text { aspects, e.g. market, } \\
\text { projectmanagement, product, } \\
\text { innovation culture, know-how etc. } \\
\text { (Warschat, 2005) }\end{array}$ & $\begin{array}{l}\text { The InnoAudit-Scorecard is an } \\
\text { instrument to classify companies } \\
\text { and to identify company-specific } \\
\text { improvement potential. (Warschat, } \\
2005 \text {, p. } 13 \text { ) }\end{array}$ \\
\hline Goffin \& Mitchell & Company & $\begin{array}{l}\text { Semi- } \\
\text { quantitative }\end{array}$ & $\begin{array}{l}\text { The indicators of this approach equal } \\
\text { the quantitative indicators of the } \\
\text { IPOO model. The output and } \\
\text { outcome indicators of the IPOO are } \\
\text { put together in Goffin's aspect output } \\
\text { (Goffin \& Mitchell, 2010, p. 316) }\end{array}$ & \\
\hline Improve & Company & $\begin{array}{l}\text { Semi- } \\
\text { quantitative }\end{array}$ & $\begin{array}{l}\text { Indicators are clustered in the } 5 \\
\text { dimensions innovation strategy, } \\
\text { innovation organisation \& culture, } \\
\text { innovation life cycle processes, } \\
\text { enabling factors and innovation } \\
\text { results. Exemplary indicators are e.g. } \\
\text { time to market / profit, feedback } \\
\text { loops, idea management, capacity for } \\
\text { innovation, etc. (Innovety, 2014, p. 5) }\end{array}$ & $\begin{array}{l}\text { Measuring the company's overall } \\
\text { innovation management } \\
\text { performance with the Improve } \\
\text { tool is based on A.T. Kearney's } \\
\text { "House of Innovation". } \\
\text { (Innovety, 2014, p. 5) }\end{array}$ \\
\hline De Jong et al & Company & $\begin{array}{l}\text { Semi- } \\
\text { quantitative }\end{array}$ & $\begin{array}{l}\text { The model includes } 50 \text { determinants } \\
\text { which are group into the } 9 \text { categories } \\
\text { people characteristics, strategy, } \\
\text { culture, structure, availability of } \\
\text { means, network activities, company } \\
\text { characteristics, innovation } \\
\text { infrastructure and market } \\
\text { characteristics. (Jong, Kemp \& Snel, } \\
\text { 2001, p. 9-10) }\end{array}$ & $\begin{array}{l}\text { The model describes the } \\
\text { determinants for innovative } \\
\text { ability. (Jong et al., 2001, p. 9) }\end{array}$ \\
\hline $\begin{array}{l}\text { Community } \\
\text { Innovation Surveys } \\
\text { (e.g. CIS Finland, } \\
\text { ZEW Germany }\end{array}$ & Company & $\begin{array}{l}\text { Semi- } \\
\text { quantitative }\end{array}$ & $\begin{array}{l}\text { Exemplary indicators are (Rammer, } \\
\text { Crass, Doherr \& et al, 2016): } \\
\text { Number of product / process } \\
\text { innovations, innovation activities } \\
\text { conducted in last } 3 \text { years, number of } \\
\text { new products, surveys with regards to } \\
\text { innovation barriers, etc. }\end{array}$ & $\begin{array}{l}\text { The data is used to measure } \\
\text { innovation output as a } \\
\text { complement to more traditional } \\
\text { measures such as patents. } \\
\text { (Leiponen \& Helfat, 2006, p. 9) }\end{array}$ \\
\hline $\begin{array}{l}\text { Michie \& Sheehan, } \\
2003\end{array}$ & Company & Quantitative & $\begin{array}{l}\text { Firms were asked: 'during the past } \\
\text { three years, how many product } \\
\text { innovations has the company } \\
\text { introduced?' and 'during the past } \\
\text { three years, how many process } \\
\text { innovations has the company } \\
\text { introduced?'. (Michie \& Sheehan, } \\
\text { 2003, p. 129) }\end{array}$ & \\
\hline "Bean counting" & $\begin{array}{l}\text { Business } \\
\text { unit }\end{array}$ & Quantitative & $\begin{array}{l}\text { Exemplary indicators are: patents, } \\
\text { technical publications, awards from } \\
\text { peer groups, etc. (Pappas \& Remer, } \\
\text { 1985) }\end{array}$ & $\begin{array}{l}\text { The objective is to quantitatively } \\
\text { measure the productivity of the } \\
\text { R\&D personnel (Pappas } \\
\text { \& Remer, } 1985 \text {, p. } 18 \text { ) }\end{array}$ \\
\hline
\end{tabular}




\begin{tabular}{|c|c|c|c|c|}
\hline \multicolumn{5}{|c|}{ Overview over discussed approaches } \\
\hline Name / Author & $\begin{array}{l}\text { Level of } \\
\text { analysis }\end{array}$ & $\begin{array}{l}\text { Measuring } \\
\text { technique(s) }\end{array}$ & Indicators used & Remarks / short description \\
\hline $\begin{array}{l}\text { R\&D Return } \\
\text { Framework }\end{array}$ & $\begin{array}{l}\text { Business } \\
\text { unit }\end{array}$ & Quantitative & $\begin{array}{l}\text { Indicators for the R\&D Return } \\
\text { Framework are (Vahs \& Brem, 2015, } \\
\text { p. 648): } \\
\cdot \text { R\&D Productivity: Potential } \\
\text { productivity and technology } \\
\text { development efficiency } \\
\cdot \text { R\&D Yield: potential yield and } \\
\text { operating efficiency }\end{array}$ & $\begin{array}{l}\text { A total value of the efficiency of } \\
\text { the } R \& D \text { department is calculated } \\
\text { in this approach }\end{array}$ \\
\hline INNO & $\begin{array}{l}\text { Business } \\
\text { unit }\end{array}$ & Qualitative & $\begin{array}{l}\text { The INNO instrument has } 21 \text { items } \\
\text { clustered in four factors: (1) activating } \\
\text { leadership, (2) continuous } \\
\text { questioning, (3) consequential } \\
\text { implementation, and (4) professional } \\
\text { documentation. (Kauffeld, Jonas, } \\
\text { Grote, Frey \& Frieling, 2004, p. 155) }\end{array}$ & $\begin{array}{l}\text { The INNO is focusing on the } \\
\text { innovation climate in companies } \\
\text { and allows a standardized and } \\
\text { economic measurement of } \\
\text { conditions facilitating innovation } \\
\text { in organizations (Kauffeld et al., } \\
2004 \text {, p. 156) }\end{array}$ \\
\hline $\begin{array}{l}\text { Team Climate } \\
\text { Indicator }\end{array}$ & $\begin{array}{l}\text { Business } \\
\text { unit }\end{array}$ & $\begin{array}{l}\text { Semi- } \\
\text { quantitative }\end{array}$ & $\begin{array}{l}\text { The Team Climate Indicator } \\
\text { measures } 38 \text { questions for example } \\
\text { with regards to (Anderson \& West, } \\
\text { 1998, p. 246) team objectives, } \\
\text { friendliness of team members, chance } \\
\text { to put forward new ideas, appraisal of } \\
\text { weaknesses, work evaluation, ways to } \\
\text { tackle a problem, etc. }\end{array}$ & $\begin{array}{l}\text { The TCI is 'a measure of group } \\
\text { climate in organizations, and for } \\
\text { team building and organization } \\
\text { development interventions.' } \\
\text { (Anderson \& West, 1998, p. 255) }\end{array}$ \\
\hline $\begin{array}{l}\text { Outcome } \\
\text { indicators for job } \\
\text { center }\end{array}$ & $\begin{array}{l}\text { Business } \\
\text { unit }\end{array}$ & Quantitative & $\begin{array}{l}\text { 'The outcomes we focus on are log } \\
\text { job entry productivity as the quantity } \\
\text { measure and the quality of service to } \\
\text { job seekers (denoted JSQ), the quality } \\
\text { of service to firms (denoted EMQ) } \\
\text { and the business delivery target } \\
\text { (denoted BDT) as the three quality } \\
\text { measures'. (Burgess, Propper, Ratto } \\
\text { \& Tominey, 2012) }\end{array}$ & Burgess \\
\hline Fuchs & $\begin{array}{l}\text { Business } \\
\text { unit }\end{array}$ & Quantitative & $\begin{array}{l}\text { number of implemented } \\
\text { improvement ideas (Fuchs, 2014, } \\
\text { p. 40) }\end{array}$ & \\
\hline Tidd \& Bessant & $\begin{array}{l}\text { Business } \\
\text { unit }\end{array}$ & $\begin{array}{l}\text { Semi- } \\
\text { quantitative }\end{array}$ & $\begin{array}{l}\text { Exemplary selection of indicators } \\
\text { (Tidd \& Bessant, 2014, p. 289): } \\
\text { · Input: e.g. percentage of sales } \\
\text { committed to R\&D, investments in } \\
\text { Training, recruitment of skilled staff } \\
\text { - Process: e.g. number of new ideas, } \\
\text { failure rates, number of overruns on } \\
\text { development time / cost budgets, } \\
\text { measures of continuous } \\
\text { improvement (suggestions/employee, } \\
\text { number of problem solving teams, } \\
\text { cumulative savings, etc.) } \\
\text { · Output: specific (e.g. patents, } \\
\text { scientific papers, new products), } \\
\text { process elements (e.g. customer } \\
\text { satisfaction, improvements in quality), } \\
\text { comparable (e.g. market share, quality } \\
\text { performance, cost of product) and } \\
\text { strategic success (e.g. revenue growth, } \\
\text { improved quality, higher value added) }\end{array}$ & \\
\hline
\end{tabular}




\begin{tabular}{|c|c|c|c|c|}
\hline \multicolumn{5}{|c|}{ Overview over discussed approaches } \\
\hline Name / Author & $\begin{array}{l}\text { Level of } \\
\text { analysis }\end{array}$ & $\begin{array}{l}\text { Measuring } \\
\text { technique(s) }\end{array}$ & Indicators used & Remarks / short description \\
\hline $\begin{array}{l}\text { Integrated } \\
\text { evaluation method }\end{array}$ & Project & Qualitative & $\begin{array}{l}\text { Indicators to assess the technology } \\
\text { and market of an innovation, e.g. by } \\
\text { value for customers, technological } \\
\text { advance compared to existing } \\
\text { products, competitor analysis, R\&D } \\
\text { lead, existence of required know-how, } \\
\text { etc. }\end{array}$ & $\begin{array}{l}\text { Technological aspects and market } \\
\text { chances of an innovative product } \\
\text { are evaluated by expert interviews } \\
\text { and workshops(Vahs \& Brem, } \\
2015,346 \mathrm{ff})\end{array}$ \\
\hline $\begin{array}{l}\text { Operative } \\
\text { innovation } \\
\text { Controlling }\end{array}$ & Project & $\begin{array}{l}\text { Semi- } \\
\text { quantitative } \\
\& \text { qualitative }\end{array}$ & $\begin{array}{l}\text { Approach is strongly focused on the } \\
\text { project oriented control of } \\
\text { innovation activities in the } \\
\text { dimensions development costs, } \\
\text { product quality and development } \\
\text { time(Fischer et al., 2015, p. } 643 \text { ) }\end{array}$ & \\
\hline $\begin{array}{l}\text { Return on } \\
\text { Investment }\end{array}$ & Project & Quantitative & $\begin{array}{l}\text { Standard return on investment } \\
\text { calculation for innovation projects } \\
\text { (Hauschildt \&Salomo, 2007) }\end{array}$ & \\
\hline Fuchs & Project & $\begin{array}{l}\text { Quantitative } \\
\& \text { semi- } \\
\text { quantitative }\end{array}$ & $\begin{array}{l}\text { Depending on availability innovative } \\
\text { performance should be measured by } \\
\text { not less than length of development } \\
\text { time, costs of development, } \\
\text { evaluation of innovativeness } \\
\text { compared to the market average, } \\
\text { turnover / profit achieved. (Fuchs, } \\
2014 \text {, p. 31) }\end{array}$ & $\begin{array}{l}\text { Based on the results from the } \\
\text { single projects the innovation of } \\
\text { the company is analyzed. (Fuchs, } \\
\text { 2014, p. 31) }\end{array}$ \\
\hline $\begin{array}{l}\text { Goffin \& Mitchell, } \\
2010\end{array}$ & Employee & $\begin{array}{l}\text { Quantitative } \\
\text { \& semi- } \\
\text { quantitative }\end{array}$ & $\begin{array}{l}\text { Use of a combination of output- } \\
\text { related and behavioral focused } \\
\text { indicators: } \\
\text { · Output-orientated: scientific } \\
\text { publications, patents, ideas generated, } \\
\text { cost savings, project goals, process / } \\
\text { service innovation } \\
\text { · Behavioral focused: innovation } \\
\text { performance rating, teamwork, } \\
\text { competencies gained. (Goffin } \\
\& \text { Mitchell, 2010, p. } 302)\end{array}$ & $\begin{array}{l}\text { Using employee level innovation } \\
\text { metrics helps on deciding about } \\
\text { rewards and recognition. (Goffin } \\
\& \text { Mitchell, 2010, p. 303) }\end{array}$ \\
\hline $\begin{array}{l}\text { Innovation } \\
\text { Competence } \\
\text { Barometer }\end{array}$ & Employee & $\begin{array}{l}\text { Semi- } \\
\text { quantitative }\end{array}$ & $\begin{array}{l}\text { Formative online self-assessment tool } \\
\text { for students and professionals and } \\
\text { tool for supporting structured } \\
\text { behavioral interviewing to select } \\
\text { innovators (supervisory rating). } \\
\text { The self-assessment consists of } 34 \\
\text { items clustered in categories } \\
\text { creativity, critical thinking, initiative, } \\
\text { teamwork and networking (Butter \& } \\
\text { van Beest, 2017, p. 33) }\end{array}$ & $\begin{array}{l}\text { EU-founded project finished in } \\
2017\end{array}$ \\
\hline Scott \& Bruce & Employee & $\begin{array}{l}\text { Semi- } \\
\text { quantitative }\end{array}$ & $\begin{array}{l}\text { The } 6 \text { items of the scale for } \\
\text { individual innovative behavior in the } \\
\text { workplace are (Scott \& Bruce, 1994), } \\
\text { e.g.: } \\
\text { · Searches out new technologies, } \\
\text { processes, techniques and/or product } \\
\text { ideas } \\
\text { · Generates creative ideas } \\
\text { - Promotes and champions ideas to } \\
\text { others }\end{array}$ & $\begin{array}{l}\text { Base for extended scales, e.g. } \\
\text { Jansen (see below) or } 13 \text { items } \\
\text { scale by Zhou \& George (Zhou \& } \\
\text { George, 2001) }\end{array}$ \\
\hline
\end{tabular}




\begin{tabular}{|c|c|c|c|c|}
\hline \multicolumn{5}{|c|}{ Overview over discussed approaches } \\
\hline Name / Author & $\begin{array}{l}\text { Level of } \\
\text { analysis }\end{array}$ & $\begin{array}{l}\text { Measuring } \\
\text { technique(s) }\end{array}$ & Indicators used & Remarks / short description \\
\hline Janssen & Employee & $\begin{array}{l}\text { Semi- } \\
\text { quantitative }\end{array}$ & $\begin{array}{l}9 \text { item scale for innovative work } \\
\text { behavior (Janssen, 2001), e.g.: } \\
\cdot \text { - Searching out new working } \\
\text { methods, techniques, or instruments } \\
\cdot \text { Generating original solutions for } \\
\text { problems } \\
\cdot \text { Acquitting approval for innovative } \\
\text { ideas } \\
\cdot \text { - Making important organizational } \\
\text { members enthusiastic for innovative } \\
\text { ideas } \\
\cdot \text { Introducing innovative ideas into } \\
\text { the work environment in a systematic } \\
\text { way }\end{array}$ & $\begin{array}{l}\text { Scale to assess individual } \\
\text { innovative behavior in the } \\
\text { workplace, three items refer to } \\
\text { each innovation stage. Scale is } \\
\text { supposed to be completed by self- } \\
\text { reports and supervisory rating. }\end{array}$ \\
\hline Zhou \& Shelley & Employee & Quantitative & $\begin{array}{l}\text { Exemplary objective measures are } \\
\text { (Zhou \& Shalley, 2003, p. 174): } \\
\text { Number of patents, patent } \\
\text { disclosures, research papers, ideas } \\
\text { submitted to employee suggestion } \\
\text { programs }\end{array}$ & $\begin{array}{l}\text { Objective measures for employees' } \\
\text { creativity may be useful for R\&D } \\
\text { departments but not in all settings. } \\
\text { For example, number of patents } \\
\text { may not be relevant in nursing. } \\
\text { (Zhou \& Shalley, 2003, p. 174) }\end{array}$ \\
\hline $\begin{array}{l}\text { Global Innovation } \\
\text { Index (GII) }\end{array}$ & Country & Quantitative & $\begin{array}{l}\text { The GII relies on two sub-indices- } \\
\text { the Innovation Input Sub-Index and } \\
\text { the Innovation Output Sub-Index- } \\
\text { each built around pillars. Four } \\
\text { measures are calculated: the two } \\
\text { named above and the overall GII } \\
\text { score and the innovation efficiency } \\
\text { ratio. Thus, there is a strong focus on } \\
\text { variables which are not applicable to } \\
\text { measure the output of a single team. } \\
\text { (Cornell University, INSEAD, \& } \\
\text { WIPO, 2014, p. } 73 \text { ) }\end{array}$ & $\begin{array}{l}\text { '[The GII] helps policy makers and } \\
\text { business leaders move beyond } \\
\text { one-dimensional innovation } \\
\text { metrics towards a more holistic } \\
\text { analysis of innovation drivers and } \\
\text { outcomes.' (Cornell University et } \\
\text { al., 2014, p. 6) }\end{array}$ \\
\hline $\begin{array}{l}\text { Bloomberg } \\
\text { Indicator }\end{array}$ & Country & Quantitative & $\begin{array}{l}\text { Used metrics (equally weighted): } \\
\cdot \text { Input: R\&D, manufacturing, hi-tech } \\
\text { companies, education, research } \\
\text { personnel } \\
\cdot \text { Output: patents } \\
\text { (Coy, 2015, p. } 7 \text { ) }\end{array}$ & \\
\hline Economist Index & Country & Quantitative & $\begin{array}{l}\text { 'The business rankings model } \\
\text { examines ten separate criteria or } \\
\text { categories, covering the political } \\
\text { environment, the macroeconomic } \\
\text { environment, market opportunities, } \\
\text { policy towards free enterprise and } \\
\text { competition, policy towards foreign } \\
\text { investment, foreign trade and } \\
\text { exchange controls, taxes, financing, } \\
\text { the labour market and infrastructure. } \\
\text { Each category contains a number of } \\
\text { indicators that are assessed by the } \\
\text { Economist Intelligence Unit for the } \\
\text { last five years and the next five years.' } \\
\text { (The Economist, 2014, p. 9) }\end{array}$ & $\begin{array}{l}\text { 'The business rankings model } \\
\text { measures the quality or } \\
\text { attractiveness of the business } \\
\text { environment in the } 82 \text { countries } \\
\text { covered by The Economist } \\
\text { Intelligence Unit's Country } \\
\text { Forecast reports. It is designed to } \\
\text { reflect the main criteria used by } \\
\text { companies to formulate their } \\
\text { global business strategies.' (The } \\
\text { Economist, 2014, p. 9) }\end{array}$ \\
\hline
\end{tabular}




\begin{tabular}{|c|c|c|c|c|}
\hline \multicolumn{5}{|c|}{ Overview over discussed approaches } \\
\hline Name / Author & $\begin{array}{l}\text { Level of } \\
\text { analysis }\end{array}$ & $\begin{array}{l}\text { Measuring } \\
\text { technique(s) }\end{array}$ & Indicators used & Remarks / short description \\
\hline $\begin{array}{l}\text { Innovation } \\
\text { Capacity Index }\end{array}$ & Country & Quantitative & $\begin{array}{l}\text { The ICI is built upon five pillars } \\
\text { composed of } 61 \text { variables. The pillars } \\
\text { are institutional environment, human } \\
\text { capital, regulatory \& legal framework, } \\
\text { R\&D and adoption and use of } \\
\text { information and communication } \\
\text { technologies. (López-Claros \& Mata, } \\
2012 \text {, p. 17) }\end{array}$ & $\begin{array}{l}\text { 'TThe Innovation Capacity Index } \\
\text { is] a tool for assessing the extent to } \\
\text { which nations have succeeded in } \\
\text { developing a climate that will } \\
\text { nourish the potential for } \\
\text { innovation.' (López-Claros } \\
\text { \& Mata, 2012, p. 1) }\end{array}$ \\
\hline $\begin{array}{l}\text { National } \\
\text { Innovative } \\
\text { Capacity }\end{array}$ & Country & Quantitative & $\begin{array}{l}\text { The innovation capacity index is } \\
\text { measured by: } \\
\text { · the proportion of scientists and } \\
\text { engineers subindex } \\
\cdot \text { the innovation policy subindex } \\
\text { (effectiveness of intellectual property } \\
\text { protection, ability of a country to } \\
\text { retain its scientists, availability of } \\
\text { R\&D tax credits for private sector) } \\
\cdot \text { the cluster innovation environment } \\
\text { subindex (pressure to innovate from } \\
\text { domestic buyers, presence of } \\
\text { suppliers of specialized research and } \\
\text { training, prevalence and depth of } \\
\text { clusters) } \\
\text { the linkages subindex (overall } \\
\text { quality of scientific research } \\
\text { institutions\& availability of venture } \\
\text { capital for innovative but risky } \\
\text { projects) } \\
\text { The data is taken from the Global } \\
\text { Competition Review (GCR).(Stern, } \\
\text { Porter \& Furman, } 2000, \text { p. } 4 \text { ) }\end{array}$ & $\begin{array}{l}\text { 'This capacity is not simply the } \\
\text { realized level of innovation but } \\
\text { also reflects the fundamental } \\
\text { conditions, investments, and policy } \\
\text { choices that create the } \\
\text { environment for innovation in a } \\
\text { particular location or nation.' } \\
\text { (Stern et al., 2000, p. 5) }\end{array}$ \\
\hline $\begin{array}{l}\text { European } \\
\text { Innovation } \\
\text { Scoreboard }\end{array}$ & Country & Quantitative & $\begin{array}{l}\text { The } 2017 \text { EIS measurement } \\
\text { framework is built on } 10 \text { dimensions } \\
\text { with a total of } 27 \text { indicators } \\
\text { structured in } 4 \text { groups: } \\
\text { - Framework conditions ( } 8 \text { indicators) } \\
\text { - Investments ( } 5 \text { indicators) } \\
\text { · Innovation activities (9 indicators) } \\
\text { - Impacts ( } 5 \text { indicators) } \\
\text { (Hollanders \& Es-Sadki, 2017, } \\
\text { pp. 8-10) }\end{array}$ & $\begin{array}{l}\text { 'The annual European Innovation } \\
\text { Scoreboard (EIS) provides a } \\
\text { comparative assessment of the } \\
\text { research and innovation } \\
\text { performance of the EU Member } \\
\text { States and the relative strengths } \\
\text { and weaknesses of their research } \\
\text { and innovation systems. It helps } \\
\text { Member States assess areas in } \\
\text { which they need to concentrate } \\
\text { their efforts in order to boost their } \\
\text { innovation performance.' } \\
\text { (Hollanders \& Es-Sadki, 2017, } \\
\text { p. 8) }\end{array}$ \\
\hline
\end{tabular}

Table 4. Overview over discussed approaches

Definition of measuring technique: Semi-quantitative techniques are basically qualitative judgements that are converted to numbers. They differ from quantitative technique in that no attempt is made to use a sophisticated formula to complete the data. Qualitative techniques are intuitive judgements (Pappas \& Remer, 1985, p. 15)

\subsection{Approaches focussing on country level}

Several approaches are focussing on country level. They all have in common that they intend to support policy makers and business leaders to decide on their investment or innovation strategies (The Economist, 2014), Cornell University, INSEAD, \& WIPO, 2017). Some of them, such as the Innovation Capacity Index (LópezClaros \& Mata, 2012) are using the same focus and methodology year for year. Others change their focus, e.g. the 
Global Innovation Index was focussing on the human factor of innovation in the report 2014 (Cornell University, INSEAD \& WIPO, 2014), in the report 2016 the theme 'innovation is feeding the world' was covered (Cornell University, INSEAD \& WIPO, 2017) or the European Innovation Scorecard changed the framework significantly for its 2017 report (Hollanders \& Es-Sadki, 2017, p. 8). Depending on the theme the focus of the analysis and of the stated comments is changing even though the measured variables stayed nearly the same. While changing the focus allows to react to actual topics, sticking to the same method increases the comparability of results.

Looking at the indicators the indices are based on one can recognise two different types:

1. Approaches covering a broad range of relevant input and output factors of innovation

2. Approaches using only key indicators

Approaches of the first type developed significantly in recent years. Early approaches do not cover a broad range of aspects - such as the National Innovative Capacity using 27 indicators with a strong focus on education, $\mathrm{R} \& \mathrm{D}$ and the use of innovative goods (Stern et al., 2000, p. 4). Recently published indices are based on far more indicators and attempt to show a broad picture of aspects describing an innovative country. The actual Global Innovation Index for example is based on a total of 81 indicators (Cornell University, INSEAD, \& WIPO, 2017), the Index on Innovation Capacity 61 (López-Claros \& Mata, 2012) and The Economist indicator on 91 criteria. (The Economist, 2014, p. 9). Even though the concrete indicators of this kind of approach are not identical, the reasoning beyond the selected aspects is similar. Generally speaking the following criteria are evaluated:

- Stability and quality of the public institutions with regard to fostering business

- Existence and development of human capital

- Easiness of doing business within the existing regulatory \& legal framework

- Good and ecologically friendly infrastructure in particular with regard to information \& communication technology

- $\quad \mathrm{R} \& \mathrm{D}$ infrastructure

- Outputs of innovation activities

Due to a lack of data availability in some countries, all approaches struggle to base their innovation index exclusively on hard data. Thus, they also use composite indicators or survey results to find the appropriate tradeoff of quality of the variables and achieving a good country coverage (Cornell University, INSEAD \& WIPO, 2017, 48f).

The 2nd type of approaches is particularly represented by the Bloomberg Innovation Index. Even though it takes similar criteria into account it is using only 6 indicators: R\&D expenditure as percentage of GDP, manufacturing, Hi-tech companies, education, research personnel and patents (patents then split in 2 groups filed and granted).(Coy, 2015, p. 8). These concepts facilitate the data collection significantly.

To conclude, recent frameworks on country level either use a wide variety of indicators while attempting to provide a concise picture of the situation or reduce the evaluation on core outputs of innovation, enablers such as the regulatory framework or innovation infrastructure are omitted.

\subsection{Approaches focussing on company or business unit level}

The variety of approaches to measure innovation on company or business unit level is high (see also Table 4). Generally speaking they can be clustered into the following groups based on their focus:

1. Being linked to the innovation process 


\section{Indicators clustered into dimensions}

3. Other approaches, e.g. with regard to innovation climate or ability

Models of the first group use the idea of measuring input - process - output of an innovation (Goffin \& Mitchell, 2010; Tidd \& Bessant, 2014, p. 289). Some authors, in particular German ones, propose to separate output (short term effect) from outcome (long term result) (Möller et al., 2011, p. 30-32) or even differentiate between output, receiving system (marketing and sales efforts) and outcome (Vahs \& Brem, 2015, p. 644). The Input-Process-Output-Outcome model (IPOO) for example uses particular indicators for each step of the company's innovation process, e.g. training cost per employee with regard to input stage or number of new products with regard to output stage (Fischer et al., 2015, p. 646). Despite the structural difference of the indicators used are quite similar, e.g. the indicator "number of patents received" is proposed by Pappas and Remer (1985), Tidd and Bessant (2014), the IPOO approach and Goffin and Mitchell (2010) or the indicator “implemented improvement ideas by Tidd and Bessant (2014) and Fuchs (2014).

However, including outcome criteria into the approach (such as market share gained by innovations, etc.)implies two consequences:

- A serious delay in being able to obtain valid measuring results. It may take years before an innovation is implemented and positive effects can be identified.

- Unless a product innovation is evaluated it will be difficult to separate the effects of the innovation clearly from the other factors which might have led to the measured increase in market share.

Next to these holistic approaches one can also find ones focussing on specific aspects of the process. To be able to specifically value the efficiency of the R\&D efforts only, the R\&D Return framework was created (Vahs \& Brem, 2015, p. 648). In this approach the R\&D productivity is valued by the potential productivity and the technology development efficiency and compared to the R\&D yield, consisting of the potential yield and operating efficiency. In addition, a rigid algorithm combining all indicators is used to calculate the R\&D return value. This framework might be transferable to other business units as well, however its indicators particularly fit to R\&D.

The frameworks described above obviously demand a sophisticated measuring or auditing system to collect and rate the required data. To simplify the data collection the bean counting approach attempts to just quantitatively measure the innovative output of an R\&D department (Pappas \& Remer, 1985, p. 18). This is done by collecting indicators such as patents, technical publications, rewards, etc. or simply by counting ideas (Fuchs, 2014, p. 40). Of course, this approach might be transferred on other business units or the whole company as well.

Within the second group one can find approaches based on the balanced score card, e.g. the Innovation Balanced Score Card (Fischer et al., 2015, p. 646). The four aspects of the normal balanced score card (Financial, customer, internal business processes, learning \& growth, (Kaplan \& Norton, 1992, p. 72)) are evaluated based on the company's vision and - in this case - innovation strategy with a strong focus on in-creasing innovation success, e.g. time to market, market share gained by R\&D (Žižlavský, 2016, p. 56). An-other advance evaluating dimensions are innovation audits. Innovation audits do not only look at performance (an output measure) but also how this performance was achieved (a process measure). This is done by evaluating dimensions such as strategy, market, product, technology etc. (Goffin \& Mitchell, 2010, p. 317). Exemplary indicators for the aspect market are change in market share, number of customer surveys, number of innovations based on customer ideas, etc. (Warschat, 2005, p. 17) or the 5 dimensions of A.T. Kearney's "House of Innovation" tool "Improve" (Innovety, 2014, p. 5).

The group of other approaches is manifold. They usually have a specific focus such as "INNO" assess-ing the innovation climate (Kauffeld et al., 2004, p. 156) or the Team Climate Indicator (Anderson \& West, 1998) or describing general determinants for innovation ability (Jong et al., 2001) (for details please refer to Table 4). Some of the criteria used are overlapping with the other approaches others are specifically adopted to the advance's specific objective (e.g. job rotation or exporting activities Jong et al., 2001). 
Even though the proposed indicators can be clustered in different groups based on their focus, they are quite often alike. For example, the indicator "number of patents" is used by process orientated approaches as well as dimensional or purely output orientated ones.

To sum up, one can find a great variety of frameworks to measure innovation within companies or business units. They differ greatly with regard to their complexity and need for data, thus the required effort to collect and analyze the data. While selecting the right approach for a specific situation a differentiating criterion should be the availability of resources required to collect and analyze the data.

\subsection{Approaches focussing on work/project team level}

Fischer and Hauschildt describe an approach for operative innovation controlling, focus sing on projects (Fischer et al., 2015, p. 643). Similarly to the Integrated Evaluation Method, indicators of a typical project controlling, such as milestone or budget controlling are proposed (Maier, Streicher, Jonas \& Frey, 2007; Vahs \& Brem, 2015). Other advances measure innovative performance of projects by length of development time, costs of development etc. compared to market average or turnover (Fuchs, 2014, p. 31) or the return of investment of innovation projects (Hauschildt \& Salomo, 2007, p. 262). These indicators are particularly working well with innovative product development projects. In addition, it is also stated that the only way to assess innovation activities is to evaluate the progress of these innovation projects (Littkemann \& Derfuß, 2011, p. 588). However, this argumentation neglects the fact that innovation within companies is not always linked to projects, but the whole company including not only project but also all organizational work teams should strive for being innovative (Fischer et al., 2015, p. 642). Thus, in addition to measuring the success of innovation projects, advances focussing on teams are required. However, within this review no specific approach with regard to measuring innovation of single organizational work teams could be identified. This contrasts the fact, that a high variety of advances on company level exists.

To sum up, approaches measuring innovation projects are closely linked to typical project controlling. Even though some of the indicators of approaches measuring innovation of companies might be transferrable, no specific framework with regard to single work teams could be identified.

\subsection{Approaches focussing on individual level}

By reviewing approaches with focus on the individual level one can cluster them based on the method obtaining the information and the indicators used.

Common methods for rating innovation on individual level are either self-assessment, expert assessment, a combination of both or acquiring archival objective data such as patents or scientific publications. Jansen (2000) for example used a self-rating approach to evaluate the innovativeness of employees. However, in the recent years there has been a continuous increase in the use of third party ratings or the combination of self-assessment and third-party rating. Alge, Ballinger, Tangirala and Oakley (2006) for example, used a peer review approach for a study on innovative performance. The combination of both is also proposed, for example combining a selfassessment survey with an expert panel of professors and innovation specialist (Choi \& Chang, 2009, p. 248) or a supervisory rating (Yuan \& Woodman, 2010, p. 330). The EU funded FINCODA project created the Innovation Competence Barometer to support experts to rate the innovation capabilities of persons but also offers a parallel self-assessment (Butter \& van Beest, 2017, p. 2).

Generally speaking, all frameworks use either output-related or behavioural focused indicators. Different schemes are used to describe the latter. They are either oriented on dimensions - such as creativity, critical thinking, initiative, teamwork or networking (Butter \& van Beest, 2017; Zhou \& George, 2001) - or, on the 3 stages of innovation (idea generation, promotion and implementation) (Janssen, 2001, p. 1043) Within both schemes the evaluated characteristics (for details please refer to Table 4) are mostly based on the 6 items of individual innovative behaviour by Scott and Bruce (1994, p. 599). These are extended and refined in the recent years (e.g. 9 items by Janssen (2001, p. 1043) or 13 items (Zhou \& George, 2001, p. 687)). They state that their approach is focused on measuring creativity and not innovation. However, by evaluating the items, e.g. 
"Develops adequate plans and schedules for the implementation of new ideas", one can assume that they intend to also cover all aspects of innovation and not only the creative steps.

The recently finished Fincoda project uses a differentiated approach with 29 questions asked during the assessment which lead to a rating of 34 items clustered in 5 dimensions within the developed barometer (Butter \& van Beest, 2017, p. 33).

By transferring objective indicators also used on company level to rate individuals one tries to make the evaluation independent from personal bias. Typical indicators are number of patents, patent disclosures, ideas submitted to employee suggestion program (Zhou \& Shalley, 2003, p. 174). However, it can be assumed that it will be difficult to rate every employee by using these indicators due to the fact that even innovative persons might not participate on a suggestion programme and only very few have the chance to file a patent at all. As Zhou and Shalley formulate it, 'number of patents might not be relevant in nursing' (Zhou \& Shalley, 2003, p. 174). To avoid this situation the combination of behavioural and output oriented measuring is also used (Goffin \& Mitchell, 2010, p. 302).

To conclude, a wide variety of frameworks exists to evaluate innovation on individual level. Even though they can be differentiated based on the method the information is obtained, all behavioural focused approaches are using similar items to measure innovation ability. They distinct themselves by the number of items used. Outputrelated measures are rarely used for the individual level of analysis. In addition, it can be stated that it is difficult to get a valid rating by using them exclusively.

\subsection{Summary}

The above narrative review suggests, first, that a wide variety of different approaches using different indicators exists today. Most of them attempt to improve their validity of results by continuously increasing the number of indicators measured. In particular, frameworks on country and individual level ask for detailed data. It can be assumed that the collection of this information might require a lot of effort. On company level the number of advances with many indicators is large as well, however, very specific approaches based on few performance indicators exists. Second, the indicators used are in some cases transferrable between the levels of analysis, e.g. number of patents is used on country level (in relation to population Coy, 2015), on company level (as absolute number (Pappas \& Remer, 1985, p. 18)) and - in case output indicators are used - on project team (Tidd \& Bessant, 2014, p. 289) and individual level (Goffin \& Mitchell, 2010, p. 302) as well.

On the contrary, no framework specifically applicable to measure innovation on the organisational work team level could be found. Comparable advances focus on teams for innovation projects, thus measuring mainly the process of implementing the innovation. Even though, some aspects of this project controlling might be transferrable on the situation of organisational work teams, it still cannot replace an advance for measuring the innovation performance of a work team, in particular if this is not working in projects. The output factor without relation to innovation projects (e.g. improvements in team spirit or process enhancements) is not covered sufficiently by these advances.

\section{Discussion}

Are there open fields for further research with regard to measuring innovation and are fitting tools offered to decision makers?

First, there are still open areas for research. The country, company and individual levels are covered by various approaches. Refining these or developing new ones by additional research might be a potential field for further research. However, of higher interest would be to compare each level's approaches with focus on the different results they provide. For example, Bloomberg identified 2014 South Korea, Germany and Sweden as top 3 countries (Coy, 2015, p. 7), the Global Innovation Index claims Switzerland, Sweden and UK to be the top 3 (Cornell University, INSEAD \& WIPO, 2014, p. 25) and The Economist Singapure, Switzerland and Hongkong (The Economist, 2014, p. 2). To analyse whether and why they come up with different results and which 
approach comes the closest to reality would be an interesting field of research. In addition, the latest approaches are characterised by increased complexity. The concept of the Net Promotor Score (Reichheld, 2003, p. 47) proved due to its immens popularity (Artz, 2017, p. 33) that simple but meaningful indicators have a high acceptance in practice. Thus, research should also focus on simplifying innovation measuring to facilitate the use and foster dissemination of the concepts.

Only few approaches specifically designed for measuring innovation exist on project team / organizational work team level. Applying common project management tools such as budget controlling, milestone planning or an ROI calculation on innovation projects seems absolutely feasible and sufficient. These tools have been created for all kinds of projects and will therefore support innovation projects as well (Hauschildt \& Salomo, 2007). However, it can be stated that the gap of frameworks on organizational work team level needs further research. Innovation will be without doubt the major factor of competitive advantage for companies (Marin-Garcia, Aznar-Mas \& Ladrón de Guevara, 2011, p. 25). Thus, the number of companies conducting activities to improve their innovation performance is high and will be rising in the next couple of years. Activities to foster innovation proposed for the team level are manifold, such as team workshops, coffee corners or whiteboard for ideas (Kahlfuss, 2013, p.255f). On the other hand, it is important in the global competition to use resources effectively. Decision makers have to focus on investments with a positive outcome. 'As Marco Iansiti of Harvard Business School has pointed out, ,after all, what a company gets for the money it spends on R\&D is what ultimately matters'.' (Goffin \& Mitchell, 2010, p. 42). Obviously, without adequate approaches to measure innovation output on team level this is not possible. Even though it is suggested to use output-oriented company level indicators for the team level as well (Tidd \& Bessant, 2014, p. 289), it can be assumed that indicators such as number of patents or publications will work appropriately for R\&D teams, but are inappropriate for other kinds of teams, in particular operative-orientated ones. To sum up, it can be recommended to intensify research on measuring innovation on work team level.

Second, do the existing advances fit to practitioner's needs? On country level, most of the approaches are currently applied and provide relevant information for decision makers. Evaluating the two different types, approaches using a high number of indicators inhibit the risk of pretending to be unbiased, particularly, if the required data is not or only partly available. On the other hand, by using only key indicators there is the risk of oversimplification. While this is a topic for additional research, the author recommends to base decisions on valid and existing data, even if not so many indicators are taken into account.

On company level, decision makers have to decide whether innovation is measured from a process view or by evaluating dimensions. For companies with an implemented balanced score card it should be the most practical procedure to extend the existing system by integrating the indicators required to cover the aspect innovation. Else, the advances reflecting the innovation process might support decision makers better due to the fact that, even the indicators are quite similar, it should be easier to identify areas of improvement if you follow the process. However, it cannot be recommended to also take outcome indicators into account because indicators should be objective and minimize the effort of data gathering and provide an objective picture of the situation (Gleich \& Schimank, 2015, p. 57). It can be stated that outcome indicators are not really objective. While it is working with product innovations or inventions (and in might also be required by law, if the company is obliged to participate the employee on the financial success (e.g. "Arbeitnehmererfindungsgesetz in Germany), a company's increase in market share or similar indicators are influenced by far more factors than just the innovation, for example political decisions or social developments. Therefore, it is very doubtful whether outcome indicators reflect an objective picture of the situation.

The existing advances to measure the success of innovation projects are very close or identical to applied project controlling. Because these tools, like cost-benefit-analysis, milestone controlling, etc., are commonly used, it can be assumed that they fulfil practitioners' needs. As stated above, there is a lack of approaches measuring innovation on organisational work team level, especially the ones not working in R\&D. In case of a need for measuring it in the short term it can be recommended to practitioners to transfer simple to use approaches from company level to the specific situation, e.g. the bean counting approach meaning to count the number of ideas created and implemented (Fuchs, 2014, p. 40) 
Various tools and services to measure an individual's innovation capacity are described in the literature or offered as services. While output oriented approaches do not mirror the situation of today's team work business practice adequately, from a practitioner's perspective the Fincoda approach can be seen as sticking out. It combines a selfassessment with an expert rating on a behavioural level and is available for use (Butter \& van Beest, 2017, p. 2).

\section{Limitations}

This paper has a number of limitations. First, the study was conducted by a single author which always inhibits a risk of bias in the selection of search strings, the coding process and the classification scheme. Second, following the systematic review approach (Pittaway et al., 2004, 139f) the approaches selected in this paper are based on well-cited articles or recent articles from mainstream management journals. They might by subject to biases such as paradigms in concept or methodology resulting in omitting approaches described in less well-known journals or those offered as business services. Third, the approaches on measuring innovation are so widespread and the literature so manifold and growing, that the same Scopus search today gives additional results and this review of 30 approaches is limited and does not represent the entire literature and methods available on innovation measuring today. However, by focussing on well-cited articles, university textbooks and well-known business methods mostly based on an academic background, and by using a systematic approach combined by a final check using Google to minimize the risk of author's bias, this study intends to be a good representation of existing approaches.

\section{Conclusion}

While other authors are focussing on identifying factors influencing the innovation level (e.g. Anderson et al., 2014), the objective of conducting this review was to present a comprehensive overview over advances and tools to answer the question whether the vast and still growing literature on innovation covered all aspects of measuring and whether there is a fit to practitioners needs. The amount of existing contributions led to the application of a four-level framework to support clustering and evaluating the approaches. It can be stated that the range and variety of approaches described in this review allow to measure innovation on nearly all levels of analysis. In general, the use of these approaches can be recommended to practitioners after tailoring to their specific situation. However, I notable shortcoming could be identified: a specific framework to evaluate innovation on the work team level, especially with regard to non-R\&D teams, is missing. Addressing this limitation would be a leap forward to evaluate the effectiveness of activities to foster innovation of work teams from a researches perspective and very helpful for practitioners. 'Every innovation carries the risk of operational failure, either due to economical or due to emotional reasons. Thus the person initiating the innovation ought to prove that the idea will have benefit for the company' (Hamel, 2014, p. 188).

\section{Declaration of Conflicting Interests}

The author declared no potential conflicts of interest with respect to the research, authorship, and/or publication of this article.

\section{Funding}

The author received no financial support for the research, authorship, and/or publication of this article.

\section{References}

Alge, B.J., Ballinger, G.A., Tangirala, S., \& Oakley, J.L. (2006). Information privacy in organizations: Empowering creative and extrarole performance. The Journal of applied psychology, 91(1), 221-232. https://doi.org/10.1037/0021-9010.91.1.221

Anderson, N., Potocnik, K., \& Zhou, J. (2014). Innovation and Creativity in Organizations. Journal of Management, 40(5), 1297-1333. https://doi.org/10.1177/0149206314527128 
Anderson, N.R., \& West, M.A. (1998). Measuring climate for work group innovation: Development and validation of the team climate inventory. Journal of organizational behaviour, 19, 235-258. https://doi.org/10.1002/ (SICI)1099-1379(199805)19:3<235::AID-JOB837>3.0.CO;2-C

Artz, M. (2017). NPS: The one measure you really need to grow?. Controlling \& management review: Zeitschrift für Controlling \& Management, 61(1), 32-38. https://doi.org/10.1007/s12176-017-0002-x

Burgess, S., Propper, C., Ratto, M., \& Tominey, E. (2012). Incentives in the public sector: Evidence from a government agency. Discussion paper series / Forschungsinstitut zur Zukunft der Arbeit: Vol. 6738. Bonn: IZA.

Butter, R., \& van Beest, W. (2017). Psychometric validation of a tool for Innovation Competencies Develop-ment and Assessment using a mixed-method design. Retrieved from: www.fincoda.eu/fincoda-blog/2017 (Last access date: July 5th, 2017).

Choi, J.N., \& Chang, J.Y. (2009). Innovation implementation in the public sector: An integration of institutional and collective dynamics. The Journal of applied psychology, 94(1), 245-253. https://doi.org/10.1037/a0012994

Cornell University, INSEAD, \& WIPO (2014). The Global innovation index 2014: The buman factor in innovation (2nd printing). Fontainebleau: INSEAD.

Cornell University, INSEAD, \& WIPO (2017). The Global Innovation Index 2017: Innovation Feeding the World. Ithaca, Fontainebleau, Geneva.

Coy, P. (2015). The Bloomberg Innovation Index. Retrieved from: http://www.bloomberg.com/graphics/2015innovative-countries/ (Last access date: June 30th, 2015).

Fischer, T.M., Möller, K., \& Schultze, W. (2015). Controlling: Grundlagen, Instrumente und Entwicklungsperspektiven (2, Šuberarbeitete Auflage). Stuttgart (Germany): Schäffer-Poeschel Verlag.

Fuchs, W. (2014). Innovation und Motivation - das Gewinner-Tandem: Ideenfindung als Unternehmensphilosophie. München: mi-Wirtschaftsbuch.

Furrer, O., Thomas, H., \& Goussevskaia, A. (2008). The structure and evolution of the strategic management field: A content analysis of 26 years of strategic management research. International Journal of Management Reviews, 10(1), 1-23. https://doi.org/10.1111/j.1468-2370.2007.00217.x

Gleich, R., \& Schimank, C. (2015). Innovations controlling: IInnovationssystem, -portfolio und -projekte erfolgreich steuern; Controllinginstrumente des Innovationsmanagements ; Optimierung des Innovationsportfolios ; erfolgreicher Einsatz, von Innovationskennzablen ; mittelstandsadäquate Umsetzung mit Excel]. Der Controlling-Berater (37). Freiburg [u.a.]: Haufe-Gruppe.

Goffin, K., \& Mitchell, R. (2010). Innovation management: Strategy and implementation using the pentathlon framework. (2nd ed.). Basingstoke: Palgrave Macmillan. https://doi.org/10.1007/978-1-137-04752-6

Hamel, W. (2014). Personelle Bedingungen erfolgreicher Innovationen. In C. Schultz \& K. Hölzle (Eds.), SpringerLink: Bücher. Motoren der Innovation. Zukunftsperspektiven der Innovationsforschung (pp. 183-195). Wiesbaden: Springer Gabler. https://doi.org/10.1007/978-3-658-06135-7_11

Hauschildt, J., \& Salomo, S. (2007). Innovationsmanagement (4., überarb., erg. und aktualisierte Aufl.). Vablens Handbücher der Wirtschafts- und Sozialwissenschaften. München: Vahlen.

Hollanders, H., \& Es-Sadki, N. (2017). European Innovation Scoreboard 2017. Research \& innovation policy. Luxembourg: Publications Office of the European Union.

Innovety (2014). Innovety LLC - Innovation Management and Operations Excellence > Services $>$ Innovation Readiness Assessments. Retrieved from: http://www.innovety.com/site/Services/InnovationReadinessAssessments.aspx (Last access date: May 12th, 2016).

Janssen, O. (2001). Fairness perceptions as a moderator in the curvilinear relationships between job demands, and job performance and job satisfactions. Academy of Management Journal, 44(5), 1039-1050.

https://doi.org/10.2307/3069447 
Jong, J. d., Kemp, R., \& Snel, C. (2001). Determinants of innovative ability: An empirical test of a causal model. Research report / [EIM, Small Business Research and Consultancy]: 0010/A. Zoetermeer: EIM, Business \& Policy Research.

Kahlfuss, B. (2013). Partizipative Innovation: Ein Konzept zur Schaffung nachbaltiger Wettbewerbsvorteile. Hamburg: Selbstverl.

Kaplan, R.S., \& Norton, D.P. (1992). The balanced scorecard: Measures that drive performance. Harvard Business Review, (1), 71-79.

Kauffeld, S., Jonas, E., Grote, S., Frey, D., \& Frieling, E. (2004). Innovationsklima - Konstruktion und erste psychometrische Überprüfung eines Messinstrumentes. Diagnostica, 50(3), 153-164.

https://doi.org/10.1026/0012-1924.50.3.153

Leiponen, A., \& Helfat, C.E. (2006). When does distributed innovation activity make sense? Location, decentralization, and innovation success. ETLA Discussion Papers, The Research Institute of the Finnish Economy (ETLA), No. 1063.

Leonidou, L.C., Katsikeas, C.S., \& Coudounaris, D.N. (2010). Five decades of business research into exporting: A bibliographic analysis. Journal of International Management, 16(1), 78-91.

https://doi.org/10.1016/j.intman.2009.06.001

Littkemann, J., \& Derfuß, K. (2011). Innovationscontrolling. In S. Albers \& O. Gassmann (Eds.), Technologie- und Innovationsmanagement. Handbuch (2nd ed., p. 587-602). Wiesbaden: Gabler. https://doi.org/10.1007/978-3-83496746-6_30

López-Claros, A., \& Mata, Y.N. (2012). Policies and Institutions Underpinning Country Innovation: Results from the Innovation Capacity Index. In A. López-Claros (Ed.), The innovation for development report 2010-2011. Innovation as a driver of productivity and economic growth (pp. 3-63). Basingstoke: Palgrave Macmillan.

Maier, G.W., Streicher, B., Jonas, E., \& Frey, D. (2007). Innovation und Kreativität. In Ensylklopädie der Psychologie (pp. 809-855). Göttingen [u.a.]: Hogrefe, Verl. für Psychologie.

Marin-Garcia, J.A., Perez-Peñalver, M.J., Vidal-Carreras, P.I., \& Maheut, J. (2012). How to assess the innovation competence of higher educations students. In XVII Congreso de Ingenieria de Organizacion (pp. 920-929).

Marin-Garcia, J.A., Aznar-Mas, L., \& Ladrón de Guevara, F.G. (2011). Innovation Types and Talent Management for Innovation. Working Papers on Operations Management, 2(2), 25-31. https://doi.org/10.4995/wpom.v2i2.926

Michie, J., \& Sheehan, M. (2003). Labour market deregulation, "flexibility" and innovation. Cambridge journal of economics, 27(1), 123-143. https://doi.org/10.1093/cje/27.1.123

Möller, K., Menninger, J., \& Robers, D. (2011). Innovationscontrolling: Erfolgreiche Steuerung und Bewertung von Innovationen. Stuttgart: Schäffer-Poeschel.

Pappas, R. A., \& Remer, D. S. (1985). Measuring R\&D Productivity. Research Management, 28(3), 15-22. https://doi.org/10.1080/00345334.1985.11756896

Pittaway, L., Robertson, M., Munir, K., Denyer, D., \& Neely, A. (2004). Networking and innovation: A systematic review of the evidence. International Journal of Management Reviews, 5-6(3-4), 137-168. https://doi.org/10.1111/j.1460-8545.2004.00101.x

Rammer, C., Crass, D., Doherr, T. et al (2016). Innovationsverbaltender deutschen Wirtschaft: Indikatorenbericht zurInnovationserhebung 2015. Mannheim: ZEW.

Reichheld, F.F. (2003). The one number you need to grow. Harvard Business Review, 81(12), 46-54.

Rousseau, D.M., Manning, J., \& Denyer, D. (2008). Evidence in Management and Organizational Science: Assembling the Field's Full Weight of Scientific Knowledge Through Syntheses. The Academy of Management Annals, 2(1), 475-515. https://doi.org/10.1080/19416520802211651 
Scott, S.G., \& Bruce, R.A. (1994). Determinants of innovative behavior: A path model of individual innovation in the workplace. Academy of Management Journal, 37(3), 580-607. https://doi.org/10.2307/256701

Spender, J.-C., Corvello, V., Grimaldi, M., \& Rippa, P. (2017). Startups and open innovation: A review of the literature. European Journal of Innovation Management, 20(1), 4-30. https://doi.org/10.1108/EJIM-12-2015-0131

Stern, S., Porter, M.E., \& Furman, J.L. (2000). The determinants of national innovative capacity. Working paper series / National Bureau of Economic Research: Vol. 7876. Cambridge Mass. https://doi.org/10.3386/w7876

The Economist (2014). Business Environment Rankings: Which country is best to do business in? Retrieved from The Economist:

http://www.eiu.com/public/thankyou download.aspx?activity=download\&campaignid=bizenviro2014 (Last access dae: April 11 $\left.{ }^{\text {th }}, 2016\right)$

Tidd, J., \& Bessant, J.R. (2014). Strategic innovation management. Chichester, West Sussex: Wiley.

Vahs, D., \& Brem, A. (2015). Innovations management: Von der Idee zur erfolgreichen Vermarktung (5., überarbeitete Auflage). Stuttgart: Schäffer-Poeschel.

Warschat, J. (2005). Der Weg zur Innovationsexzellenz: Vorlesungsunterlage vom 15.02.2005. Stuttgart.

Yuan, F., \& Woodman, R.W. (2010). Innovative Behavior in the Workplace: The Role of Performance and Image Outcome Expectations. Academy of Management Journal, 53(2), 323-342. https://doi.org/10.5465/AMJ.2010.49388995

Zhou, J., \& George, J.M. (2001). When job dissatisfaction leads to creativity: Encouraging the expression of voice. Academy of Management Journal, 44(4), 682-696. https://doi.org/10.2307/3069410

Zhou, J., \& Shalley, C.E. (2003). Research on emploayee creativity: a critical review and directions for future research. In J.J. Martocchio (Ed.), Research in personnel and buman resources management: v. 23. Research in personnel and human resources management (pp. 165-217). Amsterdam, London: Elsevier JAI. https://doi.org/10.1016/S07427301(03)22004-1

Žižlavský, O. (2016). The Use of Finanical and Nonfinancial Measures within Innovation Mangament Con-troll: Experience and Research. Economics and Sociology, 9(4), 41-65. https://doi.org/10.14254/2071-789X.2016/9-4/3

\section{(c) (1) $\$$}

Article's contents are provided on an Attribution-Non Commercial 4.0 Creative commons International License. Readers are allowed to copy, distribute and communicate article's contents, provided the author's and Intangible Capital's names are included. It must not be used for commercial purposes. To see the complete license contents, please visit https://creativecommons.org/licenses/by-nc/4.0/. 